\title{
The Crystallization of a Political Economy, c. $1580-1630$
}

Most of the traditional explanations for the so-called decline of Spain have been based on-and sometimes encouraged by-a series of stereotypes about its social values and cultural beliefs. These attitudes have been studied as derived from the mere existence of a society of orders, without considering the formal institutions in which they were based. There is, therefore, a clear danger of anachronism when speaking about the institutions and political economies of the early modern period. It is quite common to refer to the central institutions of the monarchy and the way that they interacted with local powers in order to administer violence. ${ }^{1}$ The analysis of commercial institutions has also become very common among historians. ${ }^{2}$ And, even if it is obvious that the number of institutions that can be studied here is not limited-above all if we adopt what is apparently becoming the standard definition of institutions, 'the rules of the game' so to speak - too often scholars forget to examine in any detail or depth the effects that some of the more important of those institutions (the Court, the señorios, the ecclesiastical corporations, the judicial system, and even the municipalities) had on the allocation of economic resources, to say

${ }^{1}$ See Tilly (1990). This chapter is, however, principally an attempt to enter into debate with the ideas of the new institutional economics and in particular with North et al. (2009), especially Chaps. 2 and 3.

${ }^{2}$ See Acemoglu et al. (2005) and Hough and Grier (2015).

(C) The Author(s) 2019

B. Yun-Casalilla, Iberian World Empires and the Globalization of Europe 1415-1668, Palgrave Studies in Comparative Global History, https://doi.org/10.1007/978-981-13-0833-8_5 
nothing of the historiographical obliteration of the role of informal institutions (personal rules in many cases) both in state building and in shaping economic performance. ${ }^{3}$

This chapter aims to set Spanish early modern values and cultural beliefs in their institutional context at the end of the sixteenth century. Old stereotypes will be challenged, and the moral economy of the period will be considered as derived from a political economy and a system of institutions and personal rules. This will allow a more complete and balanced vision of the effects of all of this upon economic development.

\section{Iberian Stereotypes and Cultural Beliefs in European Perspective}

For many years the so-called decline of Spain has played a major role in reinforcing a range of stereotypes, some of which have become so pervasive as to assume the role of 'national character'. ${ }^{4}$ As is often the case, some of these clichés have a basis in reality. Yet, as is always the case, they also represent a distortion of it.

The seigniorial lifestyle, a supposed aversion to commerce, and even a reputed abhorrence of manual labour and practical knowledge have been presented as causes of decline (Defourneaux 1983). Even more damning has been the use of these stereotypes to describe a turning point in the history of the country and to extrapolate supposedly national characteristics from them and from an essentialist narrative ('the Black Legend'), with the old clichés presented as crucial features of the 'Spanish way of life'.

These visions can, of course, be supported from contemporary evidence. The economy of legitimation practiced by the aristocracy (Chap. 1) has been presented as a highly irrational use of resources for families

\footnotetext{
${ }^{3}$ The economic action of the royal Court has been studied (Rodríguez-Salgado 1992, 1998), but emphasis has fallen on its impact upon economies and its impact on the rule of the game has been completely obliterated (Ringrose 1983a or López ed. 1998). In regard to the señorios, much of what is known is derived from the Enlightenment. For an attempt at revision, see Yun (2002a). To an even greater extent, the ecclesiastical economies have been the victims of these interpretations: while this view cannot be said to be entirely erroneous in its analysis and criticism, a greater refinement and balance are clearly needed. The same is true for the municipal institutions. To my knowledge no study has dealt with them from this perspective despite their importance. On the role of informal institution in other areas see Rosenthal and Wong (2011). Also P. Vries (2015).

${ }^{4}$ In reference to these questions, Sánchez Albornoz came to speak of a supposedly homo hispanicus (1976), and Defourneaux (1983) referred to the 'Spanish soul'.
} 
indebted up to their eyeballs. The spending on culture, patronage, charity, pageantry, and court luxury has been seen as proof of the truth of these stereotypes. ${ }^{5}$ In fact, many writers of the day, such as Domingo de Soto, Luis Vives, and Pérez de Angulo, underlined the prevalent ethos of the aristocracy and the employment of wealth, which was channelled into the aforementioned 'economy of legitimation': help to the poor; the foundation of religious institutions; and patronage and the demonstration-and celebration-of status through conspicuous consumption (Yun 2004, pp. 56, 269). With respect to businessmen and businesses, the impression is often very similar, and the study of middle-class families has tended to underline their attraction towards a noble way of life and even-on first impression-their desire to abandon trade. ${ }^{6}$ The famous (or infamous) prohibition issued by Philip II on foreign study, the general attempt at ideological control, and the Inquisition's efforts to censor publications lie behind the interpretation of a rejection of knowledge and learning (Kamen 1965). The picaresque and the so-called noble lifestyle have been seen as proof of the rejection of work and labour.

Yet a comparative context inevitably adds balance and proportion to this image. Many of these traits can be found in countries other than Spain (and Portugal, of course). The so-called noble way of life also existed in England, France, and even, indeed, in Holland, whose society is usually taken to embody precisely the opposite stereotype. ${ }^{7}$ The other side of the coin, the supposed rejection of commerce, can be traced back to Braudel's idea of the 'betrayal of the bourgeoisie', a phenomenon that might be found equally in these countries and, of course, in Italy. ${ }^{8}$ The rejection of

\footnotetext{
${ }^{5}$ An excellent description can be found in the handwritten manuscript Avisos politicos, históricos y morales. I am grateful to Fernando Bouza for this reference.

${ }^{6}$ See the cases of Medina del Campo, Valladolid, and Segovia, respectively, in Abed Al-Hussein (1982), Bennassar (1983), and Ródenas (1990). Rodrigo de Dueñas, of Jewish descent, was a businessman and alderman of Medina del Campo and would later be called the 'Medicis castellano'-the Castilian Medici, Caro Baroja (1978, pp. 376-887).

${ }^{7}$ For the English nobility, L. Stone $(1979$, p. 251) speaks of the need to lead 'a lifestyle in accordance with one's dignity' as being one of the most important factors in spending. For Holland, Van Nierop (1984, pp. 19-34). For France, Jouanna (1991, p. 44) and Gascon (1994, pp. 357-68). See also Schalk (1986).

${ }^{8}$ Braudel (1976, vol. II, 99-110). For France, Jouanna (1991) and Gascon (1977, pp. 303-22 y 357-68). Roland Gascon has written that the purchase of offices 'drained capital to the detriment of businesses' and weakened 'the great commercial dynasties'. What Stone calls 'the inflation of honours', with marriages between nobles and the daughters of
} 
manual labour - or the marked preference for the noble lifestyle-formed part of the era's value system. Even the phenomenon of the closing off of the guilds can be found in other regions of Europe. ${ }^{9}$

These interpretations and concepts must therefore be nuanced and balanced within quite specific historical contexts. The noble lifestyle was also part of a process that had emerged from the auxilium, including royal favours, court patronage, and the capture of political incomes in order to overcome central tensions within the dynamic of aristocratic families and networks (Chap. 4 above) (Yun 2002a, 2005a and 2005b). The economic trajectory seen from the middle of the fifteenth century demonstrated the scope for development of merchant groups of undoubted potential. Families such as the Ruíz, the Dueñas, and the Espinosa, and many others, proved not only their trading spirit but also their skills and aptitudes as businessmen and bankers. ${ }^{10}$ As was the case for their counterparts across the continent, investments in rents (juros and censos) and land were part of strategies aimed at the diversification of business and risk. ${ }^{11}$ And, as in other countries, these families employed matrimonial and familial policies that allowed them to establish their businesses, reduce transaction costs, gain access to privileged sources of information, create flexible and far-reaching commercial networks, reduce barriers on access to certain areas, and achieve social promotion for themselves and their relatives. ${ }^{12}$ The purchase of noble titles was a means of acquiring the sort of political capital that would be useful for their true interest and purpose-the reproduction of their families - which was a priority far above and beyond the financial success of their businesses. In a brilliant book, Michel Cavaillac has demonstrated the existence of what he labels 'a bourgeois spirit', a term whose value

businessmen can be considered the 'betrayal of the bourgeoisie' (Stone 1979, chapter 11). Something similar happened in Holland (Burke 1974).

${ }^{9}$ In France the artisan masters tended to consider their trade as 'a patrimony to be reserved for their sons' and sought to prevent the entrance of new members into guilds by a variety of means. In Holland the guilds also practiced restrictive measures to keep out newcomers (De Vries y Van der Woude 1997, pp. 174-6).

${ }^{10}$ Lohman (1968), Lapeyre (1955). On the diffusion of Castilian financial techniques in Europe, Van der Wee (1967).

${ }^{11}$ Lapeyre (1955), Abed Al-Hussein (1982), Carande (1987, vol. I), Casado (1997) among others.

${ }^{12}$ Abed Al-Hussein (1982), Casado (1987, p. 220). On the role of the merchants as consuls and a means to obtaining information, see the case of the Florentine Ginori, Zamora (2014), and Lobato (2013). 
might be debated but that perfectly reflects the ideal of a group that valued merit and championed commerce and work and even advocated an anti-war policy in the hope that it might help the development of business (Cavillac 1994, pp. 256-410).

Something similar might be said about the myth of there existing widespread prejudice against practical knowledge and work in Spain. The capacity for technological development offers considerable proof of how mistaken this interpretation is, although it might be added that advances were largely achieved through the influence of foreign technicians and the assimilation of new knowledge (Chap. 3). Furthermore, it is very significant that the majority of the topics discussed in the preceding pages have been taken from the works of the arbitristas, the reform-minded writers of the early seventeenth century. From 1550 to 1630, men such as Cellorigo, Mercado, Caxa de Leruela, and Diego de Deza channelled their energies into criticizing the vices of the noble lifestyle-its luxury, indulgence, and rejection of manual labour. Yet the true value of these arguments, and the reason why they were enthusiastically welcomed, was that their readers shared the authors' revulsion at noble tastes and pretensions in general and specifically their rejection of manual labour (Mackay 2006). This positive assessment of work-and in particular artisans' work-permeated many ranks of society (Yun 2007).

All of this demonstrates the futility of studying the world of social values as a self-contained reality of permanent, monolithic, and uniform concepts characteristic of national identities. This society cannot have been said to have been shaped by either a noble ethic or bourgeois spirit: neither model advances any serious attempt to understand it, as it was characterized by competing values and ideals that were often applied flexibly and pragmatically according to circumstances and conditions, which were many and varied. Cultural beliefs were not homogeneous but rather were made up by a range of rival visions, each one exerting its influence at different times and to varying degrees.

This starting point affords us a better understanding of both formal and informal institutions and the way they strengthened specific cultural beliefs.

\section{FORMAL INSTITUTIONS}

The development of what A. M. Hespanha called 'the official law' was evident in sixteenth-century Spain and Portugal (Hespanha 1989, p. 376). This was, without doubt, a step towards the standardization of laws, an 
objective which, at least theoretically, could affect transaction costs and reduce risks. The growing importance of 'official law' was manifested in a number of developments already mentioned (Chap. 2), such as the compilation of laws or the increasing role and relevance of Chancillerias and provincial courts. ${ }^{13}$ In Portugal, the appointment of non-residential judges (usually trained in official law) in the municipalities can be considered a manifestation of the same phenomenon (Magalhães 1997, p. 162). A system of royal corregidores and other types of local delegates of the king charged with the application of the law had also been extended across the Iberian kingdoms. ${ }^{14}$ In Portugal, the Ordenações Manuelinas of 1514 and the Filipinas (1595) sought to impose a greater degree of uniformity upon the town councils (Magalhães 1997, p. 162; Neto 1997, p. 152). Some examples can even be found of the growing role of official law in the enforcement of existing adherent organizations by which traders guarantied internal agreements. The Casa de la Contratación of Seville and the Casa da Índia in Lisbon represent the clearest examples of this trend. ${ }^{15}$ The training of skilled jurists and lawyers advanced quickly and even led to the emergence of a small army of law graduates dedicated to the application of the law across the entire empire. ${ }^{16}$ The compilation and diffusion of juridical norms continued throughout the reign of Philip II and resulted in compendia that would enjoy a long life in all of the Iberian kingdoms (Tomás y Valiente 1992, pp. 263-81). Very often these regiments of experts, armed with voluminous legal compilations, did not in fact engineer an unconditional support for royal absolutism; on the contrary, they underlined the need for the king to respect and uphold the rights of the kingdom in question. ${ }^{17}$ Moreover, a number of publications circulated that set out the ideal behavioural norms of the corregidores and specified how they should administer royal and seigniorial justice. The Politica para Corregidores of Castillo de Bovadilla (1597) was one of the most notable and influential of these works.

\footnotetext{
${ }^{13}$ Kagan (1981), MacAlister (1984), Casey (1983), and, for a synthesis including America, Tomás y Valiente (1992). On Portugal's judicial system, see Hespanha (1989).

${ }^{14}$ For Castile, see Lunenfeld (1987) and for Portugal, Magalhães (1997, p. 161).

${ }^{15}$ For an empirical basis for these arguments, see Fernández de Castro (2015), and for Portugal, see Ferreira (2015, pp. 82-5).

${ }^{16}$ Pelorson (1980), Rivero (2011).

${ }^{17}$ See, for example, the case of Juan Bautista Larrea in Volpini (2004).
} 
The increase in the number of cases brought before the regional court or Chancilleria of Valladolid (Kagan 1981), which proportionally far outstripped population growth, constitutes one of the best pieces of evidence for the development of the system of impersonal enforcement under the authority of judges. An eloquent demonstration of the character of this system can be found in the sociology of the cases brought before the Chancilleria of Valladolid. According to figures presented by Richard L. Kagan, the most common target of litigation was the king himself, something which can be interpreted in principle as evidence of the development of a third-party system in which the so-called parasitic absolutist king had to play by (at least) some of the rules of the game. ${ }^{18}$ After the king, the Castilian aristocracy were the group that most frequently recurred to judicial intervention, usually as the third party in a system of incentivecompatible agreements dealing in matters of dowries and matrimonial ties, transfers of inheritances, and questions related to the mayorazgo, donations, and-finally but obviously of great importance in light of what has been set out above-debts (Kagan 1981, pp. 11-2). All of this demonstrates the insufficiency and failings of the system of self-enforcement and internal agreements, which had been predominant over the previous centuries and which had often led to violent feudal confrontations (Chap. 1). In Kagan's figures the aristocracy was followed by the cities, which litigated over questions of privileges, municipal lands, and, of course, debts (the greatest single cause of hearings in Castile). Finally it can be no surprise to find ordinary subjects and peasants, the latter suing their landlords (Kagan 1981, p. 12).

As we have seen (Chap. 2), the registering of written contracts increased, as thousands of documents in Castilian, Portuguese, and Aragonese archives prove. This development was manifested in the dense network of notaries and clerks that had emerged in all of the Iberian kingdoms at the end of the century. ${ }^{19}$ They registered all types of agreements: accords for large-scale sales and purchases; contracts for the formation of companies; pledges and commitments to marry and, above all, to pay dowries (even in rural areas), both of which proved crucial for the economies of aristocrats,

\footnotetext{
${ }^{18}$ Significantly, many of the 'thousands of lawsuits' in which the king was a party were due to his duty 'to protect his vast personal patrimony' (Kagan 1981, p. 11).

${ }^{19}$ For Portugal, see Hespanha (1989, pp. 140-4). Like in the case of the judges, they were local offices.
} 
patricians, and merchants; the cartas de poder (letters conferring power of attorney for collecting specific debts or acting on behalf of a trader in general matters) exchanged between businessmen operating in distant areas; post-death inventories of goods and their division between families; and even contracts to postpone or divide the payment of debts or to arrange their repayment in distant towns.

For this reason, notarial registers were increasingly used in the Atlantic and were established in America as a means of enforcing payments and debts (Cachero 2010). The use of identical formats and structures in the documents generated on both sides of the Atlantic was indicative of a movement towards the globalization of the rules of play. It is also interesting that this type of bureaucrat, in principle dependent upon the Crownsomething which was not the case in other European regions (Yun and Ramos 2012) - emerged not only in the royal demesne lands but also in the towns under noble, ecclesiastical, and municipal jurisdiction.

As we will see further in this chapter, many of these trends created positive conditions for economic activities. But this view does not fit a reality that was much more complex.

The pact within elites and between them and the king guaranteed and even, in certain respects, reinforced both the jurisdictional role of these seigniorial estates and the private jurisdictions in general. In Castile, Aragon, and Portugal, noble and ecclesiastical estates retained some capacity of enforcement, despite the development of royal justice in the Chancillerias (Guilarte 1987, p. 203). At the root of everything was the superimposition of different laws and legal codes, which often operated in competition with one another (Hespanha 1989). Though the approval of the Crown was sometimes needed, the great aristocrats and leading ecclesiastical institutions retained their capacity of coercion and right to promulgate council by-laws (ordenanzas) that regulated social life and the exploitation of resources (García Hernán 2010). They also had the power to nominate local authorities and judges. In the Crown of Aragon, the exercise of 'absolute' jurisdiction extended the seigniors' enormous dayto-day power. Even in Catalonia, where the process was more ambiguous and nuanced, the authority of the jurisdictional landlords continued to be highly influential (Serra 1988). In Portugal things were not very different. Here, as in the rest of the peninsula, the seigniors retained an enormous jurisdictional capacity and powers of enforcement (Hespanha 1989, pp. 307-63). The importance of the nobles as nuclei for the mobilization of troops or credit (by setting debts in their mayorazgos) only strength- 
ened this situation across the peninsula. The sale of jurisdictions-something inexistent in Portugal, although the alienation of royal lands had been significant in the fifteenth century-multiplied the number of social actors who held private jurisdictions in such a way that it advanced the fragmentation of the jurisdictional map and who mediated in the Crown's capacity to apply the law, at least in the first instance (Nader 1990).

A similar process took place in the cities despite their more direct dependency upon the king. The growing power of the king through his judges or mayors (corregidores) supposed a limitation to both their autonomous capacity of enforcement and the extrajudicial imposition of the wishes of the oligarchy. But, for reasons set out above (Chap. 4), the cities and municipalities retained great control over their fiscal systems, which was decisive for economic activity. And they also maintained their capacity for coercion and even, in the final instance, for the exercise of violence, in part because of their role in military mobilizations. All of this allowed the cities to strengthen their economic activities, a process which was accompanied by the reinforcing of the ideological justification for their privileges.

Given the similarities between changes in the towns and the system of auxilium exercised by the nobility, these trends reinforced the notion of the noble status of the city as a counterweight to the more republican vision that had previously been prevalent. ${ }^{20}$ Aware of their character as a sort of collective señorio, the cities came to see themselves as a manifestation of nobility and so advanced rival claims over their ancestry and antiquity. ${ }^{21}$ This same impulse strengthened the medieval vision of the city as being responsible for the common good, a trend which reinforced a political economy which was theoretically directed to this end. ${ }^{22}$ This served as a justification for a city's economic resources and jurisdictions and strengthened its capacity for coercion. ${ }^{23}$ And the cities clearly retained

\footnotetext{
${ }^{20}$ See the case of Salamanca-many others might be mentioned-in G. Gómez Dávila, Historia de las Antigüedades de la ciudad de Salamanca, ed. Facsímil de Salamanca, 1994 [Prologue of B. Cuart; of the original edition of 1606].

${ }^{21}$ The nobility of the city was, by extension, a reflection of the noble status of its families, something which consecrated the mimicry between a city and its patriciate. See G. Argote de Molina, Nobleza de Andalucía Riquelme y Vargas ediciones: Jaén, 1991 [original edition, Jaén 1866].

${ }^{22}$ On that vision in the context of an idea of republicanism, see Skinner (2002, pp. 39-117). On the urban señorio, Castillo de Bovadilla (1640).

${ }^{23}$ The concern for the wellbeing of the poor was very clear, as was the commitment to the general good and public services (teaching, health, cleanliness), or religious observance, all of which were undertaken with the aim of creating social cohesion and a sort of collective
} 
a vigorous array of privileges and coercive prerogatives: the right to prohibit and regulate markets, such as that of wine; the power to police weights and measures; and control over prices (Hamilton 1975). Another significant right was the regulation of commerce through local intermediaries, a prerogative which was decisive for the collection of both alcabalas and millones (Chacón 1979, pp. 342-54). Especially important was the system for provisioning the city, which attempted to guaranteed the supply of bread, meat, and fish through the creation of communal granaries and the public management of grain exchanges or through the establishment of a system of contractors who, in exchange for deals with the council or mayor's office, obtained the monopoly on the trade in the product in question (see below). Moreover, the publicly funded purchase of common lands or municipal offices allowed the local oligarchies to control the use of considerable resources and functions (De Bernardo 1994).

Many cities also maintained their regulatory capacity over industrial and guild activities, which was crucial for economic development. This function became more significant when the right to allocate or distribute taxes through the branches of industry afforded it a greater degree of interventionism. In Seville the 'municipal council was increasingly responsible for the approval of the guild by-laws' until, well into the seventeenth century, this activity began to fall under the control of the Royal Council (Bernal et al. 1978, p. 100). Scholars have spoken of a growing 'municipal interventionism' in Córdoba throughout the sixteenth century (Fortea 1981, pp. 381-8).

In the short term, the institutional evolution described in previous chapters tended to preserve the rural councils (concejos) in their different juridical formats. Yet here variation was considerable. There were areassuch as Salamanca and Extremadura-where depopulation took place, with the disappearance of small villages and hamlets: this was usually caused by the expansion of the livestock economy, the interest of the nobility and big ecclesiastic landlords in increasing their direct access to

catharsis (through great processions like those of Corpus Christi, feast days, and public acts). The same can be said of the use of charity, the creation of confraternities, care for orphans, or the efforts to implant a civilizing process of courtesy or urbanity through the control over time, which led to the widespread purchase and installation of clocks in public spaces (Castillo de Bovadilla 1597). In Castile policing was important, but much more so in Aragon, largely because of the fight against banditry by cities or unions of cities (Colás and Salas 1982, pp. 289-322; Torres 1994, chap. IV). All developments were very similar to what was happening in Portugal, where the Ordenaçoes Filipinas set down functions and similar ideological programmes (Hespanha 1989, pp. 132 and ff.). 
land, or the reconsolidation of settlements. In the Crown of Castile, however, this process was not prevalent or common in many areas where the interest of the jurisdictional landlords - and specifically the importance of the tercias and alcabalas to their incomes-led them to support the survival of communities. Furthermore, the opportunities available to the seigniorial landlords to overcome financial difficulties through access to favours generated by the auxilium or easy credit may have acted as a safety valve for the pressure exerted on the peasant collectives (Yun 2002a).

These institutions underwent considerable change as a result of a combination of factors: the atomization of community relations brought about by the purchase of jurisdictions and the fragmentation of wider spaces of shared common land, a growing internal social differentiation, the concentration of property within the higher echelons of local society, the increasing domination of municipal government by elites, the ever-more common ownership of offices by leading families, and so on. But it is certain that they survived as an essential part of society and the institutional and economic arrangements described above (Chap. 3). For this reason, the rural community remained an institution that was vital to any understanding of the rules of coercion, the informal mechanisms of enforcement, and the regulation of economic activity and allocation of productive factors. This is particularly important to remember, as their domains saw the most frequent overlapping and clashes of official law and the myriad of 'non-official laws' and customs. Studies for Portugal (which cannot have been substantially different from the rest of Europe) show that it was at the level of the rural community that the various forms of law and models of enforcement (very much based upon compromise) had the greatest impact and importance (Hespanha 1989, pp. 363-77).

The process described in the previous chapters explains the survival of ecclesiastical justice and juridical autonomy. While remaining dependent upon Rome, ecclesiastical justice was faced with an increase in the capacity of royal justice to intervene, while the king's powers of mediation were also growing. At times, ecclesiastical institutions themselves required the king's intercession as a third party in their internal relations and disputes or in those with members of other religious orders. But the independence of ecclesiastical justice over the clergy remained untouched (Domínguez 1985, pp. 335-440). Moreover, the very fact that there existed such controversy over the ability of the Church to impose corporal punishment upon those members of the laity who broke its rules provides clear evidence that the ecclesiastical courts kept a good deal of their capacity for 
enforcement. Some contemporaries even justified the right of the clerics to impose these punishments for infringements such as the sale of substandard merchandise or the charging of excessive prices for goods (Domínguez 1985). A good number of institutions conceded donativos to the king-as we will see, this tendency became paramount in the seventeenth centuryand even became involved in military levies, trends which reinforced their power within their domains or allowed them to obtain new privileges. In some cases, institutions obtained exemption from the sisas de millones, or were compensated for having to pay them, concessions which reinforced their capacity for fiscal autonomy. And there was general agreement that the Church's temporal jurisdiction might be used to punish those who lent money-not only ecclesiastics - at excessive rates of interest (usury). The opposition put up by the Cathedral of Zamora to laws about contraband trade with Portugal is indicative of its institutional power to resist the king's justice (Álvarez 1987). The Church continued to wield powerful religious censures and punishments; indeed, it even threatened excommunication for economic infractions such as the failure to pay the tithe (see Chap. 4).

The developments described in the previous chapter also explain the changes and continuities in the guild system. The expansion of the urban economies reinforced artisan activities and led to the framing of guild bylaws by many artisan corporations. In this respect, cases such as those of Seville and Toledo are significant. ${ }^{24}$ It is very possible that a factor in these developments was the fiscal system (and the encabezamientos), which distributed fiscal burdens upon offices and branches of activity. ${ }^{25}$ For this reason, the continued existence of these corporations could be vital to the ability of the cities to meet their fiscal quota. In order to understand the political economy of these institutions, it is important to consider that they were not corporations dedicated to a purely economic purpose or end; rather, their primary function was to guarantee the social interests of the group from which they were formed and to ensure reciprocity between them, despite the inevitable rivalries between members of different guilds. They had many other functions beyond mere economic regulation: support

\footnotetext{
${ }^{24}$ Bernal et al. (1978) and Montemayor (1996, p. 208).

${ }^{25}$ This connection between corporations and the fiscal system deserves better study. In any case, some authors such as Nieto $(2006$, p. 200) have established that it was reinforced when, in the seventeenth century, the corporations made donativos to the Crown, which therefore had a great interest in their survival.
} 
was given to widows; assistance was provided for the burial of members; and the benefits of membership of these corporations were frequently projected into the public space through a rich visual and symbolic culture. But even more important, though in most of the towns corporations were under the city authorities' supervision, they had the function of controlling and regulating the production process, which gave them a high capacity of enforcement and coercion (see, e.g. Fortea 1981; Nieto 2006). The predominance of these functions - not only on the peninsula - explains an important feature of these corporations: their great interest in limiting competition from external competitors and in erecting entry barriers for them.

The consulates were to merchants what guilds were to artisans. The most interesting of them was, without doubt, that of Seville. As always with these institutions, the Seville consulate exercised a notable power of regulation over merchant relationships and was important in creating mechanisms of confidence-sometimes, informal ones-between its members. It was also active in resolving conflicts through nonjudicial means. This was achieved through self-enforcement and by forging private accords within the mercantile community. Of course, these arrangements existed beyond the consulates' members and their fields of operation. But the Consulate of Seville, like its counterpart in Burgos, which it imitated in many regards, also had its own justice mechanisms adjusted to the nascent Castilian commercial legal code and its growing transnational component (Smith 1978, chapters VI and VII). When traders did not reach an agreement through the Consulate-or the House of Trade (Fernández de Castro 2015) -mediation, the judges of these institutions also applied the laws of Castile in combination with more general customs and practices. They exercised a form of justice that was similar to that of the Chancillerias, above which there was only the Council of Indies and of the king himself; but they also heard cases brought against the king and, most often, against the abusive application of his fiscal measures and in many occasions the judges of the Consulate acted as 'watchful dogs' of the trader's economic interests' (Smith 1978, p. 147).

Although the Court exhibited the characteristics of a highly informal institution, it constituted one of the most important spaces for social and economic regulation in this period. The processes described in previous chapters led to the emergence of the Court as a political space in which patronage was administered and power exercised (Rodríguez-Salgado $1992,1998)$. It became a decisive institution for the administration of violence and law, both of which would shape the management of the great patrimonies and, indirectly, the country's economy. 
The composite monarchy of the Spanish Habsburgs had been constructed as a constellation of Courts. This having been said, clearly Philip II, Philip III, and Philip IV reinforced the role of Madrid Court and capital within the empire, even above the interests of Lisbon, to the great discontent of the Portuguese. ${ }^{26}$ Madrid Court was in fact the crucible where huge economic, social, and political resources were distributed and, therefore, the main arena in which the conflictive pact was substantiated. In this political space, royal grace was dispensed, and appointments (for viceroyalties, embassies, military commands, etc.) could be obtained. These conferrals constituted the other side of the auxilium and were vital to elite groups. ${ }^{27}$ Moreover, the Court was the arena where vital questions about seigniorial estates were resolved, where permissions for censos were obtained, and where contact could be made with the governmental councils, through which an array of favours could be secured for courtiers and their clients. Here the institution of marriage-determinative for the management of all estates and for noble patrimonies in particular-was arranged. And Madrid was, with Vienna, the most developed matrimonial market in Europe. Information on the political, social, and economic capital of prospective partners was available at these nodes. Three-party negotiations were entered into (with the king's involvement) over the terms and conditions of ties. In a sense, Madrid's king was the greatest 'matchmaker' in the world, as the ties decided here were questions of state, and for this reason the Habsburgs, like the Stuart kings of England (Stone 1979), had acquired the right to allow-or forbid-any prospective marriage (Atienza and Simón 1989, pp. 39-40). The Court was also a complex world of secrets and intrigues, in which the price of information, itself vital for the aristocratic economies and measurable in the cost of keeping a large numbers of clients, minions, and servants, was very high. Here accords were negotiated and strategies formed, often forcing the parties into a direct and personal relationship with the king's secretaries, administrators, and lawyers, who themselves habitually made valuable clients (Rodríguez-Salgado 1992). The rituals of power, and the need to generate the political and social capital necessary to secure the confidence

${ }^{26}$ The political and social processes can be found in different works of J. Mártínez Millán (e.g. Martínez and Morales (1998)). See also Lisón (1991) and Del Río (2000).

${ }^{27}$ See the cases of the house of Alba and Medinasidonia in Maltby (1983) and Pierson (1989). 
and reciprocity appropriate to informal institutional relationships mediated though the social ciphers of the court and its arcane manners, compelled the high nobility and those above it to maintain a continuous presence in Madrid. ${ }^{28}$

Across Europe patronage and the king's capacity to distribute economic and social resources to clients and lineages would be one of the keys to political stability. In this sense Madrid Court was unique. ${ }^{29}$ In fact, it was the balsam that made possible the relations of self-enforcement intrinsic to closed societies and that cemented the accord at the heart of the dominant coalition. ${ }^{30}$ Here the effects of globalization and empire were evident. Despite the remarkable differences between the multinational elites that converged on Madrid, this was the Court of the 'greatest lord of the world', as the Venetian ambassador, Simon Contarini, remarked in relation to Philip III, adding that these characteristics increased the king's ability to temper political ruptures. ${ }^{31}$ As an institution the Court even helped to crystallize relationships between the various nobilities of the empire (Yun 2009).

${ }^{28}$ This case is very similar to Greif's description of the great Genoese merchants and bankers (Greif 2006). Pinheiro da Veiga, a Portuguese noble in the Court of Valladolid at the beginning of the seventeenth century, described the conflict between the marquis of Tavara, 'who is very much a youth', and the duke of Infantado, 'who is very pro-Portuguese', over errors committed in the use of term of address 'señoría' and the expression 'merced' (1989 [1605-1606], pp. 115-6).

${ }^{29}$ For a very different view, see N. Elias (2000), who attributed 'the civilizing process' to the control of violence imposed upon the nobility of Louis XIV at Versailles. Here the aim is to study the court as a redistributor of incomes that palliated factional conflicts and its contribution to the consolidation of the political and social system (chapter 9).

${ }^{30}$ As elsewhere in this study, the terms employed here follow the usage of North et al. (2009), who do not, however, dedicate much attention to the court.

31 'Without touching his estate', Contarini wrote, the king 'has much to give in two ways; on the one hand, for distribution as a reward for the monetary services destined to this end; on the other, when he pays and rewards with the exercise of the offices given him, because he appoints twenty and more Viceroys [...] forty-six general captains [...] Distributes military orders, encomiendas [grants in rights to land and the services of their inhabitants] [...] those being are more than five hundred encomiendas, some worth twenty thousand ducats and the smallest five hundred [...] eight or more Archbishoprics [...] the least of which renders five thousand ducats; seventy-three bishoprics [...] most of them worth twenty thousand ducats, and none less than three thousand'. 'Relación que hizo a la República de Venecia, Simón Contarini, al fin del año 1605 de la Embajada que había hecho en España', in L. Cabrera de Córdoba, Relaciones de las cosas sucedidas en la Corte de España desde 1591 a 1614, Madrid, 1857. 
The Crown might also be referred to as an institution. It was to a large extent responsible for the progress of the Chancillerias and the juridical systems that allowed litigants to appeal to official law. At the same time, the monarchs sponsored the emergence of the scribe system, the compilation of law codes, and other changes that took place across the Iberian kingdoms. The legal treatises of the time also emphasized the importance of presenting the king as the final legal authority - that is, above the private jurisdictions - and the sponsor of these new compilations of legal codes and customs. ${ }^{32}$ The pact with the elites had helped to give political stability to the different kingdoms. The maintenance of social order, of which the king was the final guarantee, helped to create good conditions for many economic activities. ${ }^{33}$ The ability to channel the internal dynamics of the elites and deal with their need for social promotion also contributed to social stability in the cities as in the countryside.

\section{FAmily and Social Networks}

All Iberian societies-indeed, all European societies-were marked by tensions that originated in the relationships within families and extended families, lineage, and clients (Chap. 1). Family and kin relations were, without doubt, the informal institution par excellence of this society. ${ }^{34}$ Furthermore, they were important in themselves but often also the pivotal point of wider informal social networks, constructed on the base of friendship, patronage, clienteles, common local origin (paisanaje), and so on. The influence and role of the family remained very important as a result of the evolution of the elites, which allowed for its consolidation as their basic fabric.

\footnotetext{
${ }^{32}$ See the case of the Mental Law and the Ordenações Manuelinas in Portugal (Neto 1997, pp. 152-4). For Castile, the most well-known case is the (very meaningfully) so-called Recopilación de Felipe II (Philip II compilation), previously discussed. But this is one example among many others. It is interesting to note that, unlike compilations of Castile, the other kingdoms' repertoires were published with no alteration at all. That is also the reason why the Castilian ones included a mandate of enforcement in the case that they were not identical to the previous laws.

${ }^{33}$ For the same argument applied to England, see Slack (2015).

${ }^{34}$ On the internal dynamics of the family in the Mediterranean area, see Delille (2003, Chap. 4).
} 
As an institution of this kind, family, kin relations, and clientele networks (above all else, the patronage system strengthened these for both the nobility and the Crown) complied with fundamental functions. Familial networks were key to obtaining information. Nobles, like the Ataíde of Portugal, the patricians of cities such as Barcelona, or merchants, such as the Bernuy or the Ruiz of Burgos and the Echávarri of Bilbao, to say nothing of Catalan bandits such as the Nyeros and Caldells, used other members of their families to obtain information on court intrigues, city conflicts, the movements of adversaries, market conditions, and so on. ${ }^{35}$ The personal ties binding them formed the basis of the confidence relationships that allowed them to operate in various political, social, and economic circles with a degree of risk reduction and a guarantee of success. ${ }^{36}$ Institutions directly associated with familial relationships, such as matrimony, were the key to the transfer of political, social, and economic resources (this was usually achieved as dowries.) At the same time, matrimony and, specifically, the dowry served to put in motion mechanisms of self-enforcement aimed at sealing pacts or closing conflicts, sometimes ancestral in origin, between families (Yun 2002a). In all cases the family and kin ties were vital to the circulation of forms of capital through these webs. Using money to situate a son in the imperial, municipal, or ecclesiastic administration by the purchase of an office or by the foundation of a capellania (a chapel) was, for example, a way of obtaining political or cultural capital that could subsequently revert to the group in the form of incomes or the amplification of properties (Yun 2011). It may be interesting to underline that this type of practice was not exclusive to the elites. The artisans and peasants also maintained links of confidence based on familial relationships or used matrimony with very similar aims.

Family, extended blood and kin relations, and client networks, and the informal ties that accompanied them, such as friendship, permeated the entire system of formal institutions. If this is perhaps obvious, it is worth

\footnotetext{
35 These areas have been studied in great depth. For some examples, see Costa and Da Cunha (2006), Vila-Santa (2015), Ruspio (2007), Casey (2007), Priotti (2004, pp. 185-95), Casado (1997), Amelang (1986), and Torres (1994, passim and pp. 163 and ff.). On family in the Crowns of Castile and Aragon in this period, the pages written in general studies by James Casey are essential reading, above all (1989 y 1999), and his analysis of the case of Granada is excellent (2007), as are a number of works written or directed by F. Chacón; in example Chacón and Bertran (2011).

${ }^{36}$ For empirical support of this affirmation, see Casey (2007, Chap. 5).
} 
dwelling on, as it will be vital to our later discussions. The king was a 'public' institution but also a member of a lineage and a dynasty, something which affected the government of the state in many important ways. The cities and seigniorial estates were criss-crossed by, and depended upon, bloodline and affinity relationships that bound those who governed them. The same was true of the guilds and rural communities. For this reason, neither nature nor the working of these institutions can be understood without this component. That the public and private domains were so indistinct - or difficult to separate - in this society contributed to it. To give one example, in certain cases the services of a city might be rewarded by conferring privileges upon its aldermen and officials rather than upon it as an institution (see examples in Martínez Ruiz 1992). Another example: the seigniorial estate, ruled by a lineage whose interests it served, was also an essential piece in the systems for the maintenance of law, military organization, and the government of the 'republic'. The presence of familial and kin relationships within an institutional framework that was, on the face of it, modern-sometimes, indeed, erroneously studied through Weberian parameters - formed part of the symbolic projection and political language of the time. Beyond being simply a metaphor, this provided a portrait of the reality and behaviour that was expected of persons. Some time ago Otto Brunner underlined this question, placing attention on the oeconomia (literally, the ruling of the household) of the seigniorial class and the need to understand it as a form of domestic relationship (1992). In 1651 the Portuguese Francisco Manuel de Melo wrote 'that the city is a large family and the family a city in miniature' (Casey 1999, p. 192). The metaphor of the king as the father is extremely well known, as is the assimilation of the political community to the family (Walzer 1965, chapter 5).

For a long time, it has been believed that, in common with its counterparts across Europe, the aristocracy was a group subject to irrational forms of management and disinterested in its lands and possessions. ${ }^{37}$ Here it will be proposed that it is better to see it as a social group composed of individuals who operated within networks, and particularly family and lineage networks, dedicated to the reconversion of different forms of capital (Yun 2011). It is important to stress that the survival of these networks depended upon a properly functioning system of collateral payments and solidarity, as this smoothed internal tensions (Chap. 1 and Yun 1994b).

${ }^{37}$ Macfarlane (1973) and Baudrillart (1878-1880). 
The aristocratic households were in fact organizations-in the sense applied to modern firms by Simon, Cyer, and March (Yun 2011, pp. 329-32) - whose main aim was not, as classical economics would have it, economic profit maximization but rather the consolidation, coherence, and expansion of the family and lineage itself, as behavioural economics would in fact imply (Yun 1994a, 2005a and 2005b)..$^{38}$ The involvement of the great houses in the political system offered them enormous possibilities for that reconversion of social, cultural, and economic capital, which creates our impression of irrationality. In a context in which social capital was of such great importance, the investment in matrimonial alliances (dowries), in political clients (patronage), and in the promotion of the second-born sons so as to extend the power of the familial networks would be crucial (Yun 1994a). The increasing value of merit as a means of admission into this closed elite made it more necessary to invest in the promotion of military and diplomatic careers of the different members of the family and the lineage, at the same time as the acquisition of habitus that demonstrated status became more valuable, something which would also give impetus to investment in political capital for those members (Yun 2011). The increase in the king's ability to regulate relations within the nobility, manifested in his control of grace, favour, credit arrangements, and the management of the mayorazgo, made social and political resources more necessary than ever. This situation also encouraged investment in collateral payments within the lineages and the clientele networks in the forms of dowries, assistance to second-born sons, and so on, as a means of promoting members and maintaining unity by overcoming structural tensions. All of these developments combined with the dynamic created by the mayorazgo, which made family possessions inalienable and provided a shield against the dissolution of patrimonies by debt payments.

If different in important respects, the logic governing the management of ecclesiastical patrimonies displayed certain similarities. Logically, the central concern for these estates was not the family, or, to put it in a better way: the role of the family was set in different parameters. For most of the sixteenth century, the pressure created by the need for land, as well as the increase in agrarian production (and with it, a growth in tithe payments) and land rent, had allowed these ecclesiastical economies to reproduce and expand. But studies of the internal workings of the ecclesiastical corporations demonstrate that the involvement of members of noble, patrician,

\footnotetext{
${ }^{38}$ For all this, see Chap. 1 and Yun (2011).
} 
and merchant lineages became especially frequent in the sixteenth and seventeenth centuries (Cabeza 1996; Irigoyen 2001). In many cases the entrance of new members brought ecclesiastical dowries and economic contributions, sometimes in the form of lands or rents (including censos). Chapel-building and the establishment of charitable institutions and other foundations fed this trend, often being done ad personem: that is to say, a member of an important family, often a less prominent one within the lineage (a woman or second-born or illegitimate son), entered into an ecclesiastical institution bringing with him or her an economic patrimony. This was an attractive outcome for both family and ecclesiastic institutions, as it extended the patrimony of the latter and offered an outlet to internal tensions within the former, as well as adding to its symbolic capital. Consequently, the family power and prestige was subtly extended: a prominent ecclesiastical career, membership in a cathedral chapter with a significant spiritual and economic patrimony, discharging the profession of public preacher, obtaining access to consciences through confession, and so on. It is highly symptomatic that donations and foundations frequently included clauses that specifically reserved their use for a family member or for future entrants from the lineage. In this way many ecclesiastical institutions acquired possessions as an organization while surrounding themselves with a genuine constellation of donated properties that operated according to their own logic and management rules. The explosion of possessions of this sort was often predicated upon saying a set number of Masses, attracting charity or preserving capital for future relatives, priorities which were very distant from the search for productive improvements. Frequently, these foundations even drew upon resources that uncles of entrants had acquired by discharging religious functions and, in particular, by securing payments for sermons, Masses, and religious services performed on behalf of the congregations of believers (Irigoyen 2001; Latorre 1992). Graphs 5.1 and 5.2 set out the total number of foundations and those established by the high nobility. The increasing transfer of economic resources to ecclesiastic institutions - to put it the other way round, the capacity of these institutions to absorb economic resources from noble, and nonnoble, families-is impressive. This was more so if we consider that the phenomenon was not confined to elites. It can also be found among peasant families and well-off labradores (yeomen) who, on a lower scale, saw these foundations as a means of accommodating their relatives, thus smoothing internal tensions (Brumont 1984a). 


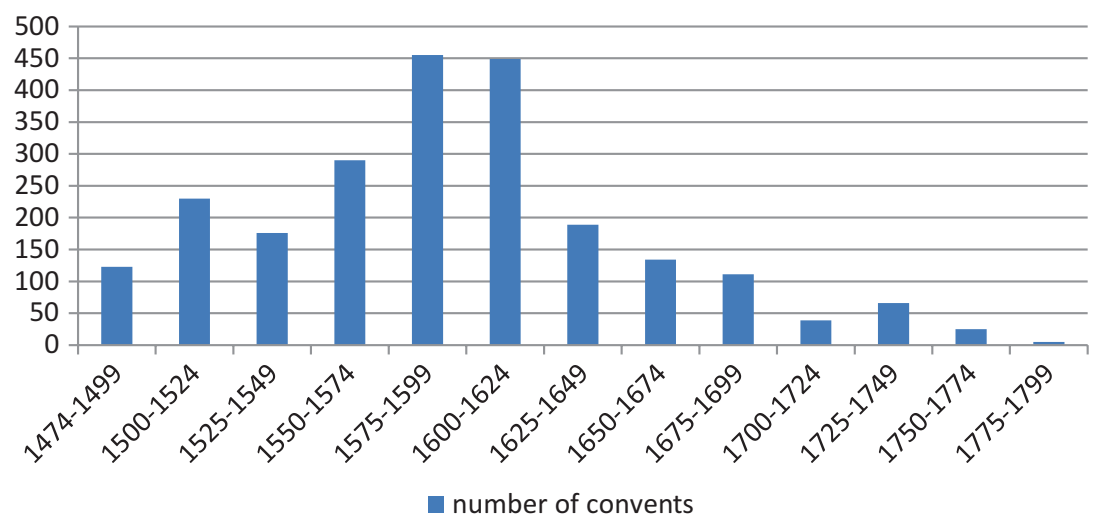

Graph 5.1 Convents founded in Spain, 1474-1799

Sources: My own elaboration with data of A. Atienza (2008, p. 33).

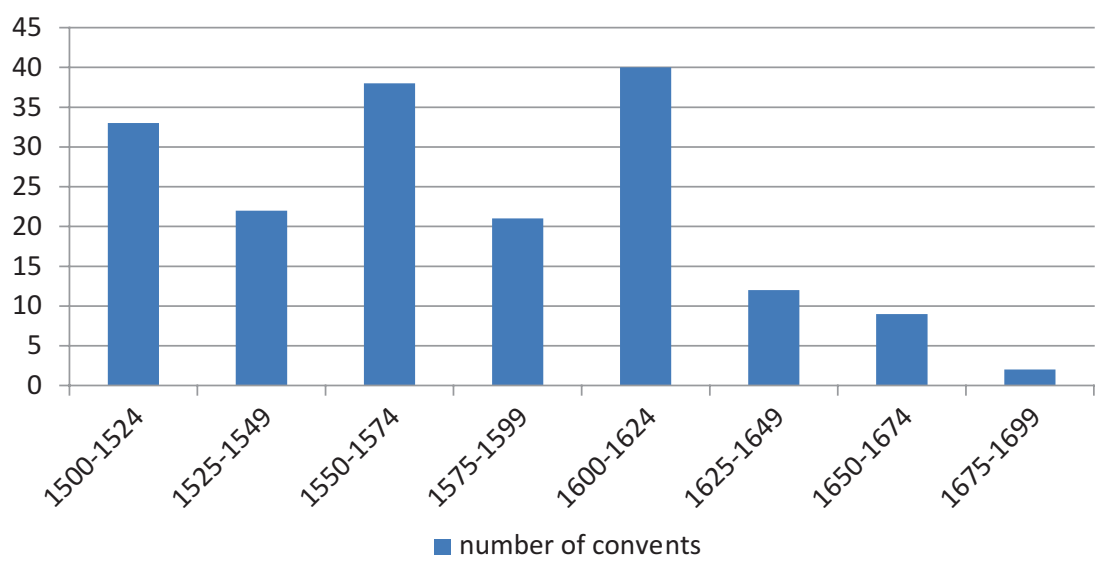

Graph 5.2 Convents founded in Spain by the main aristocratic families Sources: My own elaboration with data of A. Atienza (2008, pp. 496-519). As the author clarifies, they are approximative.

The way large merchants and urban elites in general managed their resources is also better understood if we consider them within the context of their family relations. As already explained, networks, which were also based upon family relationships, had been highly efficient in generating 
economic expansion. It should be no surprise, therefore, that the historical analysis of events following the commercial crises of the epoch has led to emphasis falling on the purchase of public debt, jurisdictions, lands, and offices, all of which is taken to be a perversion ('betrayal') of the merchants as a social group (Braudel 1976). It is easily forgotten, however, that this type of investment was structural and formed part of practices that stretched back to the medieval period (Casado 1985, 1987, pp. 485-510). These practices obeyed social values but also responded to the need to combine risky investments with more secure ones or to control spheres of power that could be decisive for businesses. In reality this meant the circulation of different forms of capital within family constellations. Cases such as those of the Burgos-Maluenda, studied by H. Casado, and the Espinosa of Medina de Rioseco (both mentioned above), or even the converso merchants who controlled silk incomes studied by E. Soria (2016), demonstrate that investments in political rents or in symbolic capital-be at the level of the kingdom or at local level—seigniorial states, lands, or municipal offices were part of a family strategy. ${ }^{39}$ Often these merchants used their daughters to transfer money through dowries, as well as to form alliances with oligarchies, patricians, and bureaucrats. For this same reason, they invested a fortune in training their sons, particularly second-born ones, who could subsequently obtain positions in the royal or municipal administration. ${ }^{40}$ This investment allowed them to place members in decisive positions and constituted a collective strategy of diversification in the forms of capital and risk, one that also sought a certain complementarity within the family as it exchanged influence for trade and then traded so as to have influence and power.

We, historians, have too often forgotten that the basic unit of management was the family rather than the business company. For this reason it was important to repeat alliances with families of other merchants, as this was their fundamental activity-hence their interest in forming matrimonial ties with other businessmen or members of the elite. Within the extended family and its multiple kin ties, there were businessmen, scribes, bureaucrats, aldermen, consuls, and even royal secretaries: in short, this was a form of establishing pathways for the circulation of influence, money,

\footnotetext{
${ }^{39}$ See the case of the Córdoba's oligarchy in Soria (2000).

${ }^{40}$ In cities such as Seville, the majority of university students came from families of lawyers or rich businessmen (Pike 1978, pp. 77, 116).
} 
prestige, security, and so on within these networks of kinship. Looked at in this light, there was a certain logic to the abandonment of business or trade based upon the forms of reconverting capital and calculating risk, not to mention the cultural beliefs of the day; when these conditions aligned, giving up 'the manual professions' by some members of these coalitions was a logical and rational move in the use of the group's resources. This having been said, in seventeenth-century Spain and Portugal, it was not easy to row back, although there certainly were those who, having adopted a noble lifestyle, continued to invest in business (Pike 1978, p. 119).

Family relationships were also crucial among artisans. As a matter of fact, their kinship dynamics, together with corporatist solidarity, were at the base of the tendency to closure of the guilds. This point deserves, however, some considerations. In many cases, the productive unit, that is the workshop, was a family unit and even part of the household. Though the studies on the interplay between family and workshops are not many for this epoch, this is evident, for example, in the case of the tanners of Madrid (Nieto 2006, p. 111), in which kin relationships were part of the managerial logic and could affect the credit system (see also Zofío 2005, chapter 5). It is not odd at all that fighting for the promotion of their sons within the profession was an important part of these families' strategies (Fortea 1981). The recent literature has also emphasized the importance of the female members of the family in the workshop. The interference of family solidarity (and not only of the family) in the guilds materialized in the purity of blood statutes (estatutos de limpieza de sangre) increasingly adopted by a number of guilds and corporations from the second half of the sixteenth century onwards in order to avoid the entrance of conversos and New Christians in general. Such prohibitions were not important because it was entirely impossible for a New Christian (and even more important for our arguments, for any person) to reinvent oneself and one's family's past or even to acquire documentary 'proof' of old Christian status. Rather it was because, regardless of the social condition of the person, the verification of any claim had to pass through a complex bureaucratic mechanism and required the mobilization of social networks to prove the absence of Jewish ancestors in two, three, or more generations. In the words of Dedieu, the statutes in reality served as the pretext for a test which, rather than focusing on origins, submitted the social power of the candidate to a severe examination' (Dedieu 1986). In fact, this institution must be understood in the context of a powerful collective movement in 
which the solidarity within the artisan families (and other social groups) was leading to the formulation of arguments based on a religious-and even racist-rationale, which, as a matter of fact, affected not only New Christians.

Like in many other institutions, the way family and the institution of guilds interlinked would be decisive.

Probably the most important institution of the day- the peasant familyhas received the least amount of attention from the theoreticians of the new institutional economics. Its working logic could vary greatly according to local contexts: the character and availability of resources, local customs, and norms; village institutions; and income levels and patrimony. But overall, the outlines are relatively evident.

First of all, we need to make clear that, as D. Reher (1990) has shown for the case of the Iberian Peninsula, the family was not in economic terms the nuclear family composed only by the couple and their sons. It is however very common to see that there were very strong personal links joining this nucleus to other relatives with whom they could often carry out economic activities.

In contrast to the elites, the principal aim of these coalitions of kinship and friendship was not the promotion of their members, although this objective might be found among the well-off (which we will see was important). Nor was the basic ambition to obtain profits, manifested in monetary stock (savings), directed to a possible investment in productive improvements. Their principal aims were subsistence and the physical reproduction of the family. This was very difficult, given the conditions of limited resources and the frequency of epidemics and famines that might easily carry away some of its members and break the family unit that constituted the basic decision-making cell. The (regionally) very different inheritance patterns were vital to the hierarchical relations with the family or community. In general, like other social groups, the family was highly hierarchical, with the men's and paterfamilias' position being decisive, although the women played a fundamental role. Women and their reproductive capability were the pivot upon which family unity turned-demographers have shown that families broke up more easily when the mother died. Given the high level of post-childbirth mortality, women were also vital in providing an abundance of workhands for the family and the assignment of its productive factors. They also constituted a crucial stock of work which, when used to produce for the market, was essential as a component of economic growth. 
Precisely for these reasons, the peasant family faced its own fragility in two challenges: to ensure that the rural community maintained a resource management policy that guaranteed subsistence; and to take maximum advantage of the available resources, sometimes in competition with other family units. Peasant solidarity, which had shone through the religious manifestations of the period (Christian 1989), has perhaps been idealized and exaggerated; nevertheless, it stood as an antidote to the enormous degree of conflict within the rural community. Trust between families, which also served to palliate conflicts, depended upon a range of qualities or conditions: good personal relationships, reputation (often based upon compliance with non-written contracts), the ability to heal wounds by recurring to forms of self-enforcement, the application of local community customs, and an appeal to the 'non-material inheritance' of some members of the community (Levi 1985). But the key point for the family economy was in fact the availability of resources, which depended on both institutions and environmental factors, as well as the economic situation of each region. These reserves were crucial during the crises provoked by bad harvests and epidemics but also depended very much on demographic pressure at a regional level.

This dependence upon factors exogenous to the family had increased due to changes in the rural community, mainly its increasing insertion in a state system and the growing influence of the more powerful rural elites who claimed a larger share of the community resources and a more strict intervention on markets' regulation.

\section{Transaction Costs, Rent-Seeking, and Allocation of Resources: A Qualitative Approach}

All of this leads to a reflection. Important steps forward had been made in the creation of enforcement systems that were increasingly uniform and that, making the application of laws more predictable across broader spaces where information on the legal rules was, normally, more expensive, could lead to a greater security in economic and social relations. A number of developments give us reason to believe in institutional advances that would be important in regard to a more rational and homogenous application of the law: the king's growing monopoly over violence, his capacity to impose himself upon other powers through patronage, and the continual presence of royal authority in important cities and councils in the person of the corregidor. 
The rolling out of written contracts, logically, led to levels of compliance and a greater probability of their being used in accords between individuals who did not know each other personally and therefore lacked guarantees based on previous personal relationships to draw upon. This development was particularly important for commerce. The written register of contracts provided the fundamental support in the expansion of institutions, such as the compagnia and the commenda, that would take root across all of Iberia and in America and which served as a formula to contribute capital and share risks.

The king's authority and agreement with elites upon the existent status quo guaranteed a higher degree of political and social stability which was very positive for the reduction of risk and transaction costs. The development of militias and the Holy Brotherhood (Santa Hermandad) contributed to the maintenance of the internal social order, thus favouring economic activities as well. The very pact with the elites and the survival of the local militias allowed the monarch to mobilize these troops against potential risings in these territories, as was made clear in the use of Castilian elites and cities in the annexation of Portugal, in the risings in Aragon, and, in the seventeenth century, in the Catalan rebellion. It is significant that Castile experienced no general social convulsions after 1521 and those that did occur were merely local conflicts. If Aragon did face internal tensions and local rebellions, then these were contained in the 1580s. As it has been said, after the fifteenth century, Portugal would be free from great domestic troubles. Banditry did not disappear from the peninsula and was very prominent in the Crown of Aragon, but in Castile and Portugal, it would be much less significant or intense. ${ }^{41}$ The cities were, of course, marked by poverty and delinquency, but they played a very minor role in the internal convulsions and kept a relatively low level of internal conflict compared to other areas of Europe (see Chap. 6). The growth of the king's powers of patronage also increased his ability to regulate social relationships and extended his capacity for enforcement; at the same time, in quite a few cases, the monarch played the role of a third party that regulated the relations between his subjects.

${ }^{41}$ The importance of banditry in early modern Castile was rightly stressed by Santos Madrazo (2000). What we want to underline here is the progress taking place during the sixteenth century. Furthermore, as long as the author considers the nobility the main protagonist of banditry, the social changes of the epoch suggest some improvements. As we will see, this is compatible with the existence of seigniorial jurisdictional coercion. 
As we said before, a new spirit of intervention and improvement of its possessions was spreading among the aristocracy (Chap. 4). ${ }^{42}$ In many areas of Castile, the seigniorial domain was not only a jurisdictional entity but more and more a set of properties in which economic improvements were possible under some circumstances. Not only the members of the high nobility but also the urban patricians and middle-rank nobles had obtained the absolute property of baldios and council lands that might be improved. In those cases in which they did not have the jurisdiction or the possibility of collecting taxes, the possibility for an amplified reproduction of capital-not based in the simple extraction of surplus-through technological or organizational innovation existed. ${ }^{43}$

The ecclesiastical institutions were not completely devoid of efforts at improvement, above all from rural convents and monasteries that were sometimes managed by 'farming monks'. In fact investments in fixed capital in the form of granaries, windmills (of flour, paper, and olives trees), and other means of production facilitating the commercialization, transformation, storage, or sale of products were far from rare (López 1990). Nor, indeed, was there an absolute lack of investment in irrigation systems or in the development of crops directed towards commercialization, such as olive trees. There were even moves towards a more rational exploitation of mountain spaces and/or livestock (this was especially true for the vocational agrarian orders, such as the Cistercians and others) (López 1990).

The development of the consulates and towns' authority could have had positive effects too. Thanks to their justice systems and capability to mediate in conflicts, both developments may have paved the way for a justice closer to the subjects and able to generate trust. The rise of a group

${ }^{42}$ This is evident in the treatises dealing with the management of aristocratic patrimonies, such as Pérez del Barrio, Dirección de Secretarios de señores y las materias, cuydados y obligaciones que les tocan (Madrid, 1613). Dedicated to the marquis of Cañete, the text explicitly sought to 'increase the estate and property' and devoted great attention to the need to administer haciendas with great care. 'They were always,' it reads, 'administered with enormous curiosity and labour, being cultivated and favoured as if a principal means of support, and enjoyed great prosperity and fruitfulness' (p. 224). The author dealt with how to 'fertilise the land', rules for extending possessions, administering offices, appointing groundsmen and keepers, book-keeping, and so on (pp. 226v-9v).

${ }^{43}$ The process, very similar in some cases to the English enclosure movement, seems in principle that could produce economic improvements. 
of letrados, trained in the Roman and common law in the universities and many of them working within these institutions (Kagan 1981), was in principle a positive development as long as it contributed to create a more homogenous system of enforcement also within consulates and cities. As a matter of fact, these letrados were the responsible for the introduction and emergence of a mercantile law with a very strong international component (Fernández de Castro 2015). As we will see, the urban autonomy might have negative effects, but it is also true that the cities' capacity to regulate the economic life within them might have been also positive for economic activities, as long as they were-or could have been-a third party in the administration of the law.

The guilds could also be less obstructive of economic change than usually thought. Over the last few years, scholars have engaged in an intense debate about European guilds, their capacity for innovation, and the reasons for their survival. This discussion has underlined their general efficiency, a characteristic that had featured in few, if any, previous assessments (Epstein 1998, 2002 among others and Ogilvie 2007). One of the arguments for the historiographical rehabilitation of the guilds in some European countries has been their ability to introduce technological innovations derived from the circulation of human capital and, therefore, to acquire technical knowledge and know-how, something which supposes a certain degree of willingness of guild corporations to allow the entrance of new members, who, of course, in principle did not have family relations with the members of the guild. Although we lack an indepth study of the Spanish and Portuguese guilds of this period, recent research on the Iberian Peninsula tends to corroborate this revisionism. It is now clear that many guild regulations were applied with great discretion and lenience-or simply not enforced at all-thus indicating far greater flexibility than has previously been thought. This was also the case with those rules that regulated the minimum age of apprentices on their admittance to the workshop (Hernández 2007). The available figures, provided in studies such as Montemayor's work on Toledo, reveal that the by-laws might be revised and adapted to changing circumstances (Montemayor 1996, p. 208). ${ }^{44}$ There was no shortage, moreover, of evi-

${ }^{44}$ Of the 30 by-laws emitted in Toledo between 1500 and 1626, 18, more than a half, were updated during the same period and, of them 10 were revised more than once. The years between the first drafts and the first revision spanned from 5 to 98 , but changes in fewer than 
dence of highly positive adaptations in some corporations until well into the seventeenth century-another indicator of greater flexibility and evidence that these guilds were more efficient in reducing transaction costs than was previously thought (Casado 2004). Above all else (Chap. 2), the development of the verlagssystem itself and the opportunities for the employment of merchant capital were considerable and suggest a more malleable system. The case of Madrid demonstrates that the number of guilds subject to the statutes of purity of blood was lower than was once thought (Nieto and Zofío 2016, p. 259). The available figures (admittedly, too few studies have been written) on the degree of openness of the guilds in the seventeenth century may be interpreted in the same way. The excellent work of Nieto and Zofío shows that $75 \%$ of the artisan masters of Madrid between 1561 and 1601 came from other provinces; in 1643-1649 this figure reached $68.2 \%$. The interpretation of these figures remains problematic, but, as the above-cited authors argue, the fact that by this date many artisans coming from outside regions did not even have to register is indicative that access to the guild was even easier than it appears.

Nieto has also underlined that there were ways of adapting to increasing demand and changes in the demand structure. The development of the verlagssystem that we have described for some towns such as Córdoba and Segovia for the sixteenth century was also present in Madrid during the seventeenth century (Nieto 2006). This change indicates also to what extent the rigidity of the guild system was not so strict and the most prominent members of the mercantile community were able to introduce changes in the productive process. Furthermore, the artisan workshop implemented a system of subcontracts to face changes and increasing demand. This system consisted in the use of specialists, sometimes belonging to other offices, in exchange for a salary to produce goods or parts of the final product for the members of the guild. The method, very rudimentary on the other side, shows in our view a certain flexibility as long as it allowed for a temporary increase in supply beyond the productive limits of the family workshops at moments of peak demand, and this was done without incurring in structural costs.

30 years were quite common. I took these data from Montemayor (1996: table of pp. 208), Of course, these figures only call for a more detailed study since it is not certain that some of the reforms served not to open or improve the workshops' economic efficiency but, rather, the opposite effect. 
From the side of the rural communities, it is also possible to find potentially positive developments. The maintenance of the rural community and the administrative structure of the concejos with their regulatory activity of the crop system kept the possibility to reduce risks and transaction costs in the use of the land. Some villages, though not many, were able to buy and to keep, which was the most difficult thing, baldios and councils' lands and incorporate them as propios that belonged to the town hall and could be used by community members in different ways. The relation between economic resources and the available land could change to a more positive equation-as it did in many regions, particularly in the interior of Castileand pave the way for an intensive use of them. In this light, it is easy to understand why the peasantry was an active agent for economic growth when there existed available productive factors at hand-including possibilities of commercialization of their surplus. These advances could be achieved by making use of the ties of confidence and solidarity that were based upon family relationships.

Therefore, the political and social development did not destroy all the possibilities of the institutional system to generate economic growth and an efficient use of resources. The key point would be in the balance between this positive side and a more negative one that we will study below.

As a matter of fact, political and social evolution would have also a less positive side. As long as it also reproduced the private jurisdictions of the nobility, the Church, and the cities, as well as their capacity of coercion, use of violence, and regulation of economic life, the outcome was also a plurality of superimposed powers, often resulting in conflict. The result could be a situation very similar to the one North et al. have defined as a closed society (2009).

This was a society of orders, with a corporate character and a huge variety of individual juridical statutes, which were, obviously, a source of fragmentation and uncertainty in social and economic relations between the different social groups. To litigate against a noble or clergyman could entail different implications, something which created marked uncertainty, as is demonstrated by the case between Belalcázar and Toledo. This was, moreover, a society with a plurality of law codes. As A. M. Hespanha has underlined for Portugal, the so-called official law was still a long way from displacing local and consensual laws: indeed, in some cases they imposed themselves upon and contradicted each other (1989). Furthermore the multiplication of laws created a certain degree of chaos. Sancho de 
Moncada dedicated some memorable pages in which he underlined the excessive number of laws ('there must be more than 5000') and their cryptic character ('they speak erroneous words'), which left a wide margin for arbitrariness for the judges, 'so that they can squeeze whoever they want' (Moncada 1974 [1619], pp. 201-2). Jerónimo de Ceballos was very probably right when he asked in 1623 :

Where has one seen, in all the countries, so many tribunals and so little justice? Where so many judges and less regard for the state? Where more laws but lawsuits settled unevenly? And where such multitude of lawyers, notaries, and scribes, but so little attention paid to the causes of the poor, the young, and the widowed? ${ }^{45}$

The old custom of 'obeying but not complying' created limits on the king's capacity of enforcement and transferred decisions to corporations of citizens, above all to the cities and the Cortes, thus adding some additional uncertainties. Many conflicts were in the end resolved by systems of self-regulation before arriving before the tribunals and even, indeed, after having done so. As R. Kagan has written, this society was litigious to the point of exhaustion and might recur to the tribunals-and the cases brought before the House of Trade of Seville give grounds for suspecting the same (Fernández de Castro 2015) — not to resolve a conflict but simply to put off decisions. For this reason it is not unreasonable to suppose that going before the chancelleries in search of justice was, despite being increasingly frequent, bitterly criticized by a part of contemporary society and that 'an arbitrated settlement within the confines of the community was the preferred mechanism for ending disputes' (Kagan 1981, p. 18). In other words, a system of corporative self-enforcement was very often preferable to a decision reached by judges and the use of official law. Moreover, when trying to make use of the tribunals, the important thing in many cases was to decide the court or third party before which the suit would be brought, as this detail could be decisive in the application of the law rather than the letter of it. And the collision of laws and the superimposition and confrontation of juridical spaces could only increase uncertainty. Even if the decision remained in the hands of the judge, the effect of precedent or unwritten law in shaping decisions was inherent to the system itself. This meant that the circumstances of the case-the personality, merits, prior

${ }^{45}$ Arte real para el buen gobierno, 1623 (quoted in Kagan 1981, p. 210). 
services and lineage of the parties, and many other factors besides - that were very difficult to foresee could have a marked effect on the verdict, and so the application of the law was unpredictable ex ante. ${ }^{46}$

The problems are evident in relation to the fiscal system. If in one town a certain tax had been levied in sisas upon a product, in the next town it might be set upon another product. Such a disparity was the outcome of a growing degree of local-level autonomy in the management of taxes. In many cases - the millones, for example - the methods for the collection of services conceded by the Cortes had to be approved by the king, but the proposals from the towns could differ. Likewise, what in the final instance mattered most was not so much how revenues were collected but rather the enormous variety of collection methods that appeared on the economic and fiscal map. There were even those towns that complied with the servicios by using their own municipal budgets (sometimes renting the propios or municipal goods, usually lands), whereas in other villages new taxes on consumables paid by commoners had to be introduced and collected. ${ }^{47}$ Furthermore the collection of taxes was shaped by informal networks of local oligarchies, which meant that a situation of 'unpredictable arbitrariness' for any outsider arose, with a very noticeable tendency towards heightened risks. ${ }^{48}$ This situation very clearly became worse during the seventeenth century as we will see (Chap. 8) and would be denounced as such in the 1700s. Vicente Alcalá Galiano described it in a book whose very title is highly expressive of the problems and which concluded with this advice:

The contribution paid to the State by each one of its individuals should be clear and set out, not arbitrary. The time and means of payment should also be specified, and the tax payers should be informed of both of these details. Because, without this knowledge, he is exposed to the injustice of the tax collector, who can raise and lower the tax when it suits his interests and caprices. Any uncertainty in the imposition of taxes encourages the insolence and corruption of those who depend upon the collection of the royal patrimony and can take hold of it without any fear; [and it is clear] that the

\footnotetext{
${ }^{46}$ See also in this respect Fernández de Castro (2015).

${ }^{47}$ The leeway enjoyed by rural communities that controlled their own alcabalas was proportionate to their ability to pay the quantities allocated to them by using their own possessions; this was the case until the 1570s, at least (García Sanz 1987, pp. 333-5).

${ }^{48} \mathrm{I}$ discussed this in the context of the theories of a new institutional economics in Yun (2001).
} 
uneven level of contributions will not bring about nor can have such a prejudicial effect to the people as can that uncertainty. ${ }^{49}$

The problem was even worse for interregional trade, where the distance increased the difficulties in acquiring the correct information about local markets, which were very heterogeneous and opaque, as Regina Grafe has demonstrated (Grafe 2012). The aims of social and (above all) commercial networks were to reduce costs, to facilitate the transfer of information, and to create the confidence that the formal institutions could not provide. But the difficulties posed by the kaleidoscopic array of local laws and taxes are more than obvious.

Finally, it is worthwhile remembering that the progress in the implantation of 'official law' ran parallel in the different kingdoms. In other words, the plurality of pacts between the Crown and each one of its kingdoms led to the preservation of a mosaic of jurisdictional systems, all of them highly different. Sometime previously the various legal systems had borrowed or stolen from one another, but all retained their previous characteristics (Tomás y Valiente 1992, pp. 232-97). This meant that the prospect of the creation of a homogenous juridical-economical space was increasingly distant, something which affected transaction costs in operations conducted across their political borders.

Some details, moreover, suggest that much of the progress achieved in sixteenth-century Castile was reversed relatively quickly from the end of the century. From 1580 the activity and efficiency of the Chancillerias were clearly reduced. This growing ineffectiveness can be measured in the number of decisions passed down by the best-known example (the Chancilleria of Valladolid), which fell from around 1400 in 1580 to between 200 and 400 in $1640-1660 .^{50}$ And if part of this reduction evidently was due to the interest in presenting great lawsuits in the Court or before the Council of Castile, it is worthwhile taking into account that there were relatively few of these major cases and that this fall was even more rapid than the decline in population. Furthermore, a study of the

\footnotetext{
${ }^{49} \mathrm{~V}$. Alcalá Galiano, Sobre la economía política y los impuestos. Academia de Artillería de Segovia, Segovia: 1992, facsimile edition, p. 321. [original edition, Segovia 1781-1788].

${ }^{50}$ According to Kagan (1981), the phenomenon was in part due to the progressive replacement of the Chancellery by the Council of Castile after the transfer of the Court to Madrid. But even then, the facts are highly suggestive, as the same conclusion appears from calculations made by subtracting the cases generated in the city itself from the total number.
} 
delays in law cases demonstrates that those of less than two years' duration fell by a notable proportion from 1560 to 1620 (from almost 50\% to $34 \%$ ), whereas the proportion of cases that lasted for eight years or more did not fall and may well have risen. ${ }^{51}$

What were the causes of this process? From its inception, the chancellery system was highly criticized, with elites and the aristocracy being both vocal and active in protesting against lawyers and this new judicial order. ${ }^{52}$ Around 1600 this opinion had taken root among the arbitristas, many of whom represented the concepts of the urban patriciate. As many of them rightly pointed out, the costs incurred in law cases were bankrupting peasants, businessmen, seigniors, and, of course, cities (Moncada 1974 [1619], pp. 201-4). But these criticisms do not appear to have weakened the justice system. As J. Owens has underlined, the problem lay in the contradiction between the wish for a solid and efficient judicial system and the fact that the king could not maintain himself without the backing of the aristocracy on the one side and the mid-ranking nobility and urban patriciate on the other (Owens 2005, pp. $182 \mathrm{ff}$.). Indeed, this argument might be taken further than Owens himself allows. After 1580 the powerful private jurisdictions, consolidated within the conflictive pact between Crown and elites, were able to compete with royal jurisdiction (Thompson 1993, vol. II, p. 223).

The crisis of the chancellery system was, very possibly, the result of a combination of factors: the growing inefficiency of these courts due to the difficult relationships between their judges and the monarch (Kagan 1981);3 economic problems and the spiralling debts of cities, seigniors, municipalities, and private individuals, which meant that recurring to slow-moving and inefficient tribunals was an ever less attractive option; and-highly important — the continued vigour of the city and seigniorial

${ }^{51}$ Kagan (1981, p. 7, Fig. 1). These figures must be treated with care, as the final judgement was emitted 'only upon request of the victorious party'. But it is very important that the figures of the author show that from 1620 the royal arrangements worked out as cheaper than the cartas ejecutorias. In spite of this, there occurred a reduction in numbers at least until 1660.

${ }^{52}$ Kagan (1981). For Quevedo's criticism of the lawyers, pp. 72-3.

${ }^{53}$ Although this area remains (unfortunately) poorly studied, it is obvious that many judges and lawyers entered into the dynamic of clientele systems, which also allowed them to achieve social ascent and to be promoted to other positions offering greater remuneration outside of the judiciary (Kagan 1981). 
jurisdictions, a lasting feature of the conflictive pact, and the recourse to informal accords between parties.

The monarch himself was also a source of instability and violence that might run against the common law and create uncertainty and risks for economic activities. Despite the nuances introduced above, the reasons and arguments of Acemoglu, Johnson and Robinson (Chap. 4) are basically correct as it comes to the negative effects of bankruptcies and the seizure of American cargoes and treasures (2005). Obviously, the Habsburgs were not exceptional in many of these measures, and it is even possible that other monarchs were more arbitrary or less sensitive than them (see Sardone 2018). It is also important to remember that, after these measures, there were negotiations that alleviated the financial damage they induced. ${ }^{54}$ But it is difficult to believe that they could not affect ex ante the feeling of risk and uncertainty, since those negotiations were always fraught and of an uncertain end.

This negative side of absolutism will become even more evident during the seventeenth century with the repeated devaluations of money, an action that, as theologists like Mariana denounced, was a gesture of tyranny that went against the kingdom's laws. The authority of the king, moreover, and his absolute power might serve as a brake on the positive effects caused by the development of justice and the chancellery courts, even in Castile itself. The exercise of absoluta potestas by the king over the chancelleries could be the cause of arbitrary actions. It was on behalf of his absoluta potestas that Philip II could settle an important lawsuit in Toledo in favour of the count of Belalcázar against the Archbishop of Toledo, without paying heed to previous judicial decisions and acting solely as a result of the political alliances at Court (Owens 2005). Moreover, it is possible to think that Philip II was much less given to this type of interference than his sons, above all Philip III. But all that was needed to create a sense of risks and higher transaction costs was the feeling that the lawsuits would be resolved not according to the letter of the law but in reference to the person against whom one litigated.

Though a relatively high degree of social order was a goal of the monarchy and its agreements with elites, the differences among the distinct

${ }^{54}$ Years ago historians such as Lovett (1977), Ruiz Martín (1990b), and RodríguezSalgado (1992) devoted very detailed studies to the way the big Genoese bankers got compensations for these actions. 
kingdoms were many. In Aragon, the pact with elites was made in more challenging conditions because of the absence of American silver and the improbability of establishing fiscal-financial relationships similar to those in Castile (Yun 2004). This had made the Crown fiscally weaker and reduced its capacity of enforcement, resulting in positive effects in some cases. The reduced ability to palliate internal conflicts within the Aragonese, Valencian, and Catalan nobility was one of the reasons for the persistence of banditry and the related difficulty in maintaining law and order. In proportion to the development of seigniorial jurisdiction, this created a higher degree of insecurity whose impact upon economic activity is not known but-according to contemporary evidence-appears to have been negative until well into the seventeenth century (Chap. 8) (Torres 1994).

But the way laws and customs were enforced is not enough to understand the allocation of resources. We also need to consider other less positive aspects of the institutional development and to what extent they also effected the criteria for the management of those resources-above all, after having previously pointed out some possible positive effects.

Regarding the señorio, and in spite of the changes, efforts to improve the methods of collecting rents and monitoring patrimonies were still more important than organizational or technical advances. ${ }^{55}$ As a general rule, the forms or types of property rights were also influential. Lands ceded in enfiteusis could not be the object of any (legal) productive improvement from the lords' side, and in a moment of demographic crisis, the actions from the peasants' side would not be frequent for several decades. ${ }^{56}$ In areas such as Valencia and Aragon, the seigniors wielded considerable juridical rights and enforcement powers. These prerogatives guaranteed the collection of their rents and the defence of their economic privileges and so lessened the need to recur to formulas for the amplified reproduction of capital. ${ }^{57}$

The development of the Court had similar effects. Rather than investing in their properties, for many aristocrats a more rational policy was to

\footnotetext{
${ }^{55}$ Pérez del Barrio (1613, p. 235).

${ }^{56}$ Here the role of the señor might be simply to promote the actions of his vassals (Pérez del Barrio 1613, pp. 226v-9v), although this might be increasingly difficult in a moment of demographic recession.

${ }^{57} \mathrm{On}$ the role of privilege and coercion in preventing economic improvements, see North et al. (2009).
} 
redouble the amount of attention paid to the Court and intensify efforts to acquire extraordinary resources through political action, a determination that would elevate the practices of rent-seeking to a prevalent feature of the management of the great houses. ${ }^{58}$ Moreover, aristocratic economies came to be based on an essential duality that explained the strange combination of luxury and indebtedness into which many of them fell. The aristocratic patrimonies were made up of two interconnected but different parts. On one side, there were the mayorazgos (composed mainly of seigniorial estates) whose incomes and management were subject to requirements and rules set down by the king. These were possessions whose use was restricted in the sense that they were tied down and almost always unmoveable; they could not be sold off or alienated in any way, and their capacity for generating liquid incomes could also be very limited. On the other side, there existed the favours, offices, pensions, and extraordinary incomes conceded by the Crown to the aristocrats, which constituted disposable sources of revenue that could be used immediately.

The result was a very asymmetric form of management. Being the mayorazgo, a non-alienable and subject to the king's unpredictable requirements and exigencies, the interest of the landlords in the improvement of their productivity was very limited. At the same time, the incomes provided by the mayorazgo were used as a means of obtaining political incomes and power, while the extraordinary incomes derived from royal grace and favour were only used in exceptional circumstances to improve the entitled properties. Such management criteria were the key to the coexistence of luxury and need that, in our eyes, appears an open contradiction but which served as a basis for a moral economy whose overall consequences would be decisive (Yun 1994a). A moral economy of this kind, tied to a series of increasingly firmly rooted cultural beliefs, existed throughout Europe. But it was manifested in Spain, above all in Castile, in a more pronounced way and with more evident consequences.

As has been said, forces to reduce incentives for improvements existed also among the ecclesiastic institutions. The exercise of privilege and specific property rights over land and rents held by these institutions would

\footnotetext{
${ }^{58}$ See the account records held in Simancas. According to my calculations, the count of Lemos, for example, enjoyed 'extraordinary' (additional) income, which came on top of those 'normal' ones derived from his seigniorial estates: the former brought in around 440,000 ducats in 1630 (Dirección General del Tesoro, inv. 1, lib. 5, exp. 81. AGS). These extraordinary revenues were numerous. See Yun (2002a).
} 
also affect their management criteria. As had occurred with the mayor$a z g o$, the very character of ecclesiastical property-also, by definition, inalienable-led to rentier forms of management, in which important improvements were not necessary to maintain the patrimony intact. Privilege, in this case embodied in an exclusive type of property right, played a fundamental role. As in the lay señorios, the notable capacity for enforcement wielded by many of these institutions allowed them to collect their incomes and, in some cases, led to the use of (not necessarily physical) coercion as a substitute for investment. Moreover, the make-up and nature of their incomes could also further reduce the attraction of introducing improvements: the collection of foros, of tithes, and of other gabelles required improvements in the forms of monitoring rather than advances in the productive system. The extension of ecclesiastical properties and their tax privileges reinforced the monopolistic advantages of some institutions in the local markets, therefore increasing their temptation for speculative management rather than for economic investments (Álvarez 1987).

In many regions such as the Duero Valley or Galicia, ecclesiastical properties were made up of small plots of land dispersed over considerable distances (the result of unordered and unplanned donations) which were rented out on short-term leases. This greatly complicated the introduction of improvements for both the farmers themselves and the institutions that owned them. From the end of the sixteenth century, the control of rural credit in the form of censos consignativos gave rise to mechanisms for the extraction of peasant income that made agrarian improvements even more unnecessary from the clerics' side. Moreover, these censos consignativos became a way of obtaining the ownership of the land itself when borrowers defaulted on their repayments, thus achieving an 'extensive' (simple) reproduction of capital. This became especially clear when the brutal series of epidemics and poor harvests that began in the 1590s combined with the sale of common lands and resulted in the ruin of many farmhands and workers. At least until economic conditions changed at the end of the century, the way many ecclesiastical institution managed credit could be negative for economic growth, and that seems to have been the case. The model of economic expansion of these institutions based on donations from the society and in particular from the elites constituted a form of rent-seeking, in this case one that was not orientated towards the Court and the state (as was that of the aristocracy) but rather towards society as a whole. Family strategies also became incrusted or fossilized, therefore, in 
the economic management of ecclesiastical patrimonies and encouraged a simple form of reproduction for these institutions. The extension of the ecclesiastic patrimony through these strategies was more important than investment in productive improvements. ${ }^{59}$ It is worthwhile remembering that war stood at the basis of all of these developments and that armed conflict was presented in religious terms as the only way to justify the taxes derived from it and the efforts and sacrifices demanded from society.

Regarding the commercial institutions, if the consulates could have positive effects in reducing risks and transaction costs among their members, the opposite effect was also very much present. This would be patent in the evolution of both the Consulate of Seville and the Casa da India of Lisbon. One of the keys to this was found in the systems for the control of colonial commerce associated with both empires.

When trade with America boomed from the last third of the sixteenth century, it became necessary to compensate the very high value of the silver cargoes and the arrival of other commodities with a balancing flow of exports to the New World (Hough and Grier 2015). Given the difficulties in meeting this demand with peninsular production alone (Chap. 7), the result was the massive entry of foreign goods, channelled through Seville, into America (Oliva 2004). It should be emphasized that this process was only made possible through the informal and family ties between Seville businessmen and foreign merchant communities. At the same time, this situation created the basis for a new relationship between Crown and Consulate. The Seville merchants-and the Consulate of the city, above all-had long provided financial assistance to the king in the form of fiscal 'advantages'; from the end of the sixteenth century, contributions of this kind would become regular (Oliva 2004). This arrangement led to forms of commercial management that were largely based on advantages derived from privileges and forms of rent-seeking. In this context, and in light of the notable benefit of intermediation with foreign industrial products, another salient aspect of commercial management is easily explainable: the reduced interest of merchant capital in general and of Seville capital in particular, to invest to dynamize industrial production in Spain. Furthermore, this combination of institutional restrictions based upon the

\footnotetext{
${ }^{59}$ The fact may be seen in the scarce, if not non-existent, quantities that were dedicated to these effects in the Cathedral of Huesca (Latorre, 1992). For the cathedral chapels of Portugal, see da Silva (2013).
} 
use of privilege and the permeability of the system to the informal institutions like the family created significant entry barriers for non-members of the merchant coalition that pivoted upon Seville. Acemoglu, Johnson, and Robinson are probably correct when arguing that the Seville monopoly served to slow down the institutional development of the country and prevented the establishment of positive institutions. But, having said this, what is certain is that emphasis should fall on the image of a parasitical yet weak king rather than on an all-powerful one.

Something similar happened with the Lisbon merchant communities, although their point of departure was different. As in Castile, the Crown had established control mechanisms for trade with the colonies, particularly with Africa and Asia. This meant establishing taxes through the control of commerce. For this reason, the monopoly meant the king's direct involvement in commerce and especially the pepper trade. By the second half of the century, however, it was becoming clear that this control was insufficient and that, moreover, fraud, contraband, and Dutch commerce could not be constrained. This led to the introduction of a system for the licencing of commerce. In exchange for a set payment, permission was granted to private businessmen to trade with Asia and Africa. This arrangement brought two advantages for the Crown (or, at least this was the hope): it obtained funds derived from the payment of the licence and fiscal yields based upon this commerce. But, as in Castile, the intrusion of informal family networks into the system ended up perverting it. In a very short space of time, a large number of non-Portuguese families became involved in this commerce; these traders were often associated with dense international networks of Jewish businessmen originating in Portugal. As in the case of the Castilian monopoly, it was an 'international monopoly' (or, in other words, it was not a monopoly), in which merchants from many countries were involved, and the commercial management was based upon the exploitation of privileges and institutional advantages that rendered unnecessary any forms of investment designed to make the country's economy more dynamic. Equally and, again, as in Castile, these practices were brought about by a weak political system that was incapable of imposing institutions upon dynamic international commercial networks rather than by a parasitical monarchical absolutism that allowed no right of appeal against its mandates and structures.

Also a good part of the urban elites were tempted by ways of management that were in principle less propitious for the general efficiency of the 
economy. This situation is partly explained by the development of the political system and the methods chosen for the promotion of relatives within the family networks. Some of these families enhanced their relations with the Crown, thus acquiring the chance to obtain a position within the empire and the formidable array of political incomes that it offered. Emigration to America and Asia (in the case of Portugal), which was especially marked among the middle class, also played a role in permitting this group access to additional (and expanding) resources, thus reproducing a scheme little conducive to economic improvements in the peninsula. Many members of the rising urban classes saw the foundation of mayorazgos as a means of not only obtaining security for them and their families but also of enlarging their social and cultural capital. ${ }^{60}$ The reinforcement of the city as a political organism, and the influence of these elites in the town councils, allowed them to apply practices of rent-seeking and so take advantage of this institution and the privileges it conferred. The investment in political capital was often more profitable than in productive improvements, which were always risky and uncertain; moreover, they were not easy to achieve, as in many cases they implied a challenge to the status quo and entrenched rights-for example, in the forms of land use, the cultivation system, and artisanal regulations.

In these circumstances, a logical and attractive policy for the local elites was to regulate the local market and the use of the recently purchased communal lands in their own benefit. Another option was the advantageous sale of goods in local markets that were heavily controlled by the town, thus creating important entrance barriers to potential competitors. ${ }^{61}$ The private use of the public domain, directly or by an intermediary, might allow elites not to embark themselves in forms of production that involved greater risks and higher transaction and monitoring costs. ${ }^{62}$

Artisan families and the way they acted within corporations could also lead to not very much fertilizing management. Their attempts to limit competition among them and with outsiders could have that effect.

\footnotetext{
${ }^{60}$ See Guerrero Mayllo (1993), Hernández (1995), Soria (2000), Ruíz Ibáñez (1995), Owens (1980), Gutiérrez (1989), and De Bernardo (1994).

${ }^{61}$ Castillo de Bovadilla recognized that entrance barriers and the high degree of privilege that local powers wielded on behalf of oligarchies were prejudicial to external agents, citing in particular the justifications given for the conferral of offices (1597).

${ }^{62}$ See many of these practices in Ruiz de Celada's book, El estado de la Bolsa. Op. cit [1777]; see Yun (1990) and also De Bernardo (1994).
} 
In many Castilian guilds, it was normal to restrict the number of apprentices that each master could take on and train. The temptation to impose restrictive policies by creating entry barriers and opposition to innovation was also present. Furthermore, the most dynamic craftsmen in seventeenth-century Castile, those of Madrid, found in a corporatist closure the best way to fight against the economic crisis after 1630 (Nieto 2006, pp. 205). The tendency to increase the money paid by the officials for the fees of the exam to become masters was also among the usual management practices, as was the tendency to reserve this status for the sons of the masters (Nieto 2006, chapter 11), to the extent that an author has spoken of endogamy and 'endotechnology' (Nieto 2006). In Córdoba the reaction against the arrival of Morisco artisans (who were especially skilled in silk production) appears to have been entirely negative, and not only because of religious prejudices, despite the prior existence of a considerable group of Moriscos in the city. ${ }^{63}$ Such an event is also a proof of the many obstructive ways that might characterize the guild's policy. Furthermore the case of Madrid on which this revisionism is based so far can be also considered as a special case as long as, at least until 1630, it was the most dynamic centre of the peninsula thanks to the installation there of the Court. The figures of newcomers to the capital's workshops must have been an exception to the peninsular rule, and the low percentage of foreigners $(6.6 \%$ in $1643-1649)$ is indicative of a relatively limited capacity

${ }^{63}$ In the aftermath of the Morisco rebellion, an important part of this minority, employed in activities of an industrial kind, was transferred to the city, creating a range of problems. Without doubt these difficulties had a religious motif, but they were also economic in nature. In certain sectors, such as silk weaving (which represented a long tradition within the history of the Moriscos of Granada), opposition among the Córdoba guilds to the newcomers was entrenched (it was extremely strong among the Old Christians). As is ever the case, the newcomers were criticized for their lack of knowledge, their production of low-quality goods (accusations which it is difficult to take seriously, as the very opposite was probably true), and, very significantly, for allowing women to work, an accusation that has been considered by Ogilvie as a proof of the closing — off of the guilds. Purely fiscal considerations (a large portion of the taxes collected by the city depended on them) meant that the Moriscos could always count upon the support of the mayor's office and the Chancellery of Granada, while the king was generally supportive of them. Yet one thing is certain: the Moriscos were expelled from Córdoba in 1609 with great clamour and popular celebration. The same was true across Castile and Aragon, but this form of mass rejection was not simply religious in origin: apart from other things, these 'new Christians' were also an economic threat to many craftsmen who defended themselves with their guild privileges. 
to absorb technical advances originating from outside the country. But even in Madrid, the conflicts among the different professions and workshops-sometimes in the king's courts — reflect a high level of tension that also leads one to suspect high transaction costs in litigation and fights. As we said previously, the case of Madrid is also meaningful in that it is not entirely implausible to think that, at least in Castile, the forms of tax collection favoured sclerosis in the corporations. Some technological advances or profound organizational change could alter the basic niches of tax collection and even lead to the disappearance of some of the corporations, something which could result in a problem for the city authorities. The result was a tendency to defend, at least in the short term, the different corporations (each of them normally associated with a phase of the productive process), which in effect reduced the possibility of major increases in productivity and which, moreover, could be easily presented as a measure introduced for the common good. ${ }^{64}$

Also among peasants and rural communities, there were ways of using resources that were not so positive. Moreover, the evolution of the rural councils, which previously had been highly dynamic institutions supporting economic growth, could now rebound to the detriment of their members. Highly refined devices and systems for the exploitation of land and property rights, upon which a very fragile balance of resources had been based, might now serve as an obstacle to the introduction of qualitative changes capable of meeting the challenge posed by a larger population. And this was also largely because these changes threatened to rupture the social equilibrium and the rules of community. For the well-off peasants it was now easier to recur to the use of communal regulations to serve their own interests than to initiate uncertain processes requiring massive change. Their ambitions to

\footnotetext{
${ }^{64}$ The most eye-catching case is that of Córdoba, where opposition among local patricians and merchants involved in the verlagssystem served as a brake on innovations that were proposed to control and transform the phases of the process of production. As Fortea showed (1981), this was one of the keys to the disruption of the development of 'capitalist' (sic) forms of productive organization and the final crisis of the sector. Even in Toledo interesting innovations and adaptations occurred in certain sectors (such as silk production), and it has been possible to affirm that the office system, being well structured and organized, 'consolidated the established situation, encouraged parasitism, but discouraged new initiatives. In this way, it ended by depriving Toledo of all chance of recovery' (Montemayor 1996, p. 214).
} 
control municipal positions, to link with families of letrados and bureaucrats, or their habit to transfer resources to the Church by funding capellanias, obras pias, and so on, has been clearly demonstrated (Brumont 1993, pp. 321-36). In other words, for elites, to convert economic into political and cultural capital was also a way to manage their patrimonies. This habit has even a rationale: by controlling municipal offices and enhancing their own prestige, they had the opportunity to mediate in the councils and in the regulation of resources in their own profit. For the peasant elites, market regulations, the use of the propios or municipal goods, and the administration of taxes were sometimes better and for sure less risky than the introduction of agrarian improvements. They could not even imagineas historians sometimes appear to want them to-the development of agrarian capitalism, which historians have often linked to the emergence of large farms or estates. But, on the other hand, this limitation meant that the communitarian system itself lost much of the productive potential that brought considerable benefits in the sixteenth century.

The institution, established to try to engineer reciprocity and maintain a sort of zero equilibrium among peasants based upon a previous status quo and formal property rights, was decisive in limiting any profound change. As we shall see, only by taking into account economic variables such as demographic pressure, the demand to buy and rent land, the development of rural markets, and so on can the different degrees of efficiency of the distinct agrarian systems be explained. Only when these variables combined in such a way that it proved possible to increase quantities of labour and natural resources without breaking the community rules was it possible for millions of individual decisions to lead to a greater degree of efficiency in the fight against death. As we shall see, the situation would be very different to that of the sixteenth century; moreover, each region would be a law unto itself.

One of the most frequent errors made when analysing the institutions of the ancien régime is to classify them as inefficient in relation to those of today's capitalist economy; another is to judge them purely by their similarity to the ideal model we have of them. There can be no doubt that, from this perspective, the study of the reigning political economy in the Iberian Peninsula around 1600 leads inexorably to a negative conclusion. 
Even when they do not accept the stereotypes and values of the new institutional economics, many historians of early modern Spain have arrived at similar conclusions. In reality, this is a legacy of Enlightenment thinking, a key moment in the development of the political economy, which saw the birth of concepts of progress and economic growth and reflections on the role of institutions that fed it. Until very recently, these perspectives and assumptions survived largely unchallenged.

But viewed from the perspective of the period, the panorama must be not only more complex but also more open in explaining efficiency quotas and growth that, obviously, belonged to a galaxy very far removed from those of the nineteenth and twentieth centuries. What emerges from the previous pages is that formal institutions and informal institutions, like the family and kinship relations, matter to explain economic behaviour and the reduction of transaction costs. But that analysis also shows that the institutions per se are not the sole point for the explanation of economic efficiency. ${ }^{65}$ They were in many occasions twofold and could lead to different behaviours of the economic agents (Helpman 2004). The crucial point would lay in the circumstances that gave preference to individual decisions with more positive effects for the whole economy-often based on individual choices whose end was not at all economic development.

Many of the affirmations set out in the previous pages might be applied to other countries. The key point, therefore, is not that the Iberian political economy was ill and, therefore, inefficient but to what extent it was competitive in a more and more integrated world. The crucial aspect is to define to what extent these institutions were able to satisfy the needs of countries that had to defend their empires and also to what extent they were able to compete in a world in which both political and economic rivalries were becoming more severe and global. To look at the problem in this way also demands a regional perspective, as does consideration of the extent to which the positive and negative potentialities of the institutional system were more or less prevalent. This task will be undertaken in the following chapters.

${ }^{65}$ For a more quantitative analysis that reinforces this idea, see Ramos (2012). 
Open Access This chapter is licensed under the terms of the Creative Commons Attribution 4.0 International License (http://creativecommons.org/licenses/ by $/ 4.0 /$ ), which permits use, sharing, adaptation, distribution and reproduction in any medium or format, as long as you give appropriate credit to the original author(s) and the source, provide a link to the Creative Commons licence and indicate if changes were made.

The images or other third party material in this chapter are included in the chapter's Creative Commons licence, unless indicated otherwise in a credit line to the material. If material is not included in the chapter's Creative Commons licence and your intended use is not permitted by statutory regulation or exceeds the permitted use, you will need to obtain permission directly from the copyright holder.

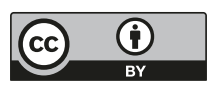

